\title{
Current trends in British dairy management regimens
}

\author{
M. D. March, ${ }^{1}$ M. J. Haskell, M. G. G. Chagunda, F. M. Langford, and D. J. Roberts \\ Scotland's Rural College (SRUC) Research, King's Buildings, West Mains Road, Edinburgh, EH9 3JG, United Kingdom
}

\begin{abstract}
This paper presents a summary of results from a 2012 survey that investigated feeding and housing management regimens currently adopted by dairy farmers in Britain. Responses from 863 farms provide a snapshot of dairy industry structure and a description of the range of management systems currently in operation. Outcomes highlight a diversity of management practices, showing that $31 \%$ of farms maintained a traditional grazing system with no forage feeding indoors during the summer, whereas $38 \%$ of farmers indicated that all their milking cows received some feeding indoors during the summer. A system of housing dairy cows for $24 \mathrm{~h} / \mathrm{d}$ while they are lactating was implemented by $8 \%$ of farms, whereas $1 \%$ of farms did not house their cows at any time of the year. Statistical analyses were carried out on 3 distinct groups identified from survey responses: (1) farmers who did not undertake any indoor feeding during the summer; (2) farmers who fed all their milking cows indoors during the summer; and (3) farmers who continuously housed their cows for $24 \mathrm{~h} / \mathrm{d}$ while lactating. Results showed a significant relationship between management type and herd size, and between management type and breed type; on average, herd sizes were larger within systems that feed indoors. No significant relationship was found between management type and farm location when classified by estimated grassland productivity. The results indicate that traditional all-summer grazing is no longer the predominant system adopted by dairy farmers and that other systems such as all-year-round indoor feeding and continuous housing are becoming more prevalent in Britain.
\end{abstract}

Key words: dairy, management system, confinement

\section{INTRODUCTION}

Britain has a long history of dairying, farmers currently produce 11.5 billion tonnes of raw milk annually, and the country ranks 10th among worldwide producers

Received April 22, 2014

Accepted August 23, 2014.

${ }^{1}$ Corresponding author: maggie.march@sruc.ac.uk in terms of volume (DairyCo, 2013c; FAOSTAT, 2013). National and "average farm" statistics reveal that the British dairy herd has dwindled from 2.3 to 1.5 million cows since 1996 (DairyCo, 2014c). At the same time, dairy production holdings have declined by more than $60 \%$ and in 2012 there were fewer than 12,000 farms in Great Britain (DairyCo, 2014a). Reductions in animal and producer numbers have been offset by an increasing average yield per cow, which has increased from 4,700 to $>7,000 \mathrm{~L}$ since 1980 (DairyCo, 2012) and by increases in the number of farms producing $>2$ million liters of milk (DairyCo, 2013a). Having fewer dairy farms operating with increased numbers of higher-producing cows is not solely a British trend and has been reported in other European Union countries (EC, 2012) as well as the United States (USDA-NASS, 2010).

Demand for a year-round milk supply means that although some British farmers can take advantage of favorable grass growth, others choose to adopt systems with a greater reliance on conserved or imported feeds. Many farmers also use composite dairy production systems that lie somewhere in the range from lowinput pastoral to high-input purchased feed-based approaches. Calls have been made to communicate, to all stakeholders, the merits of adopting a variety of milk production systems (Alvis et al., 2012), and lack of information on feeding systems has been identified as a barrier to reducing the environmental impact of milk production (DairyCo, 2009).

There is very little published information regarding the prevalence of dairy housing and feeding regimens on British farms, and such data could assist stakeholders and policy makers in the planning of proposed production increases following the removal of quotas. The proportion of housed dairy cows in Britain is also of interest to scientists studying the effects of a range of housing systems on the behavior and welfare of these animals (Haskell et al., 2006, 2013). The aim of this study was to carry out a farmer survey to assess the distribution of production methods across dairy farms in Britain to develop a reference measure.

\section{MATERIALS AND METHODS}

Data collection was managed by the Cattle Information Service (CIS; Rickmansworth, UK) which con- 
ducts milk recording throughout Britain, and surveys were completed by farmers at farms visited by CIS for milk recording purposes in May and June 2012. Some farmers did not wish to participate; however, all had the opportunity to answer the questions and a total of 863 surveys were returned from a possible 1,879 farms visited, giving a response rate of $46 \%$. Table 1 lists the survey questions, and Figure 1 shows a flowchart of the numbers of responses from question 3 (excluding questions 4-6 that relate to dry cow housing, which was not analyzed in this study). As well as answering the questions, respondents indicated their herd size, breed type, and county of residence.

Results were collated in Excel (Microsoft Corp., Redmond, WA), and distributions of herd size, breed type and county location were collated and compared with the United Kingdom (UK) national figures. The surveyed farms were located across Great Britain (GB; England, Scotland, and Wales). Some respondents completed the questions but chose not to include all or some of the response variables such as herd size or farm location; these surveys were included in the analysis of management type. Eleven responses were incomplete; these surveys were included in the response total, but were not analyzed as no management type could be determined. Of the 863 surveys, 31 respondents did not provide the size of their herd, 82 did not indicate breed type, no county response was given by 32 respondents and, within these groups, 18 surveys contained none of the 3 variables. The survey questions were designed to ensure that all possible UK dairy feeding and housing practices were captured; hence, by completing the survey, respondents could categorize their own herd into their respective management type groups. Before approaching farmers, the survey was sent to industry specialists to check that the questionnaire did indeed cover all possible types of dairy management.

To distinguish any differences between management style groups, data sets of management type responses that corresponded to 3 key UK dairy system types identified by DairyCo (2012) were analyzed and management styles were characterized as follows: (1) grazing:

Table 1. Dairy farm management survey

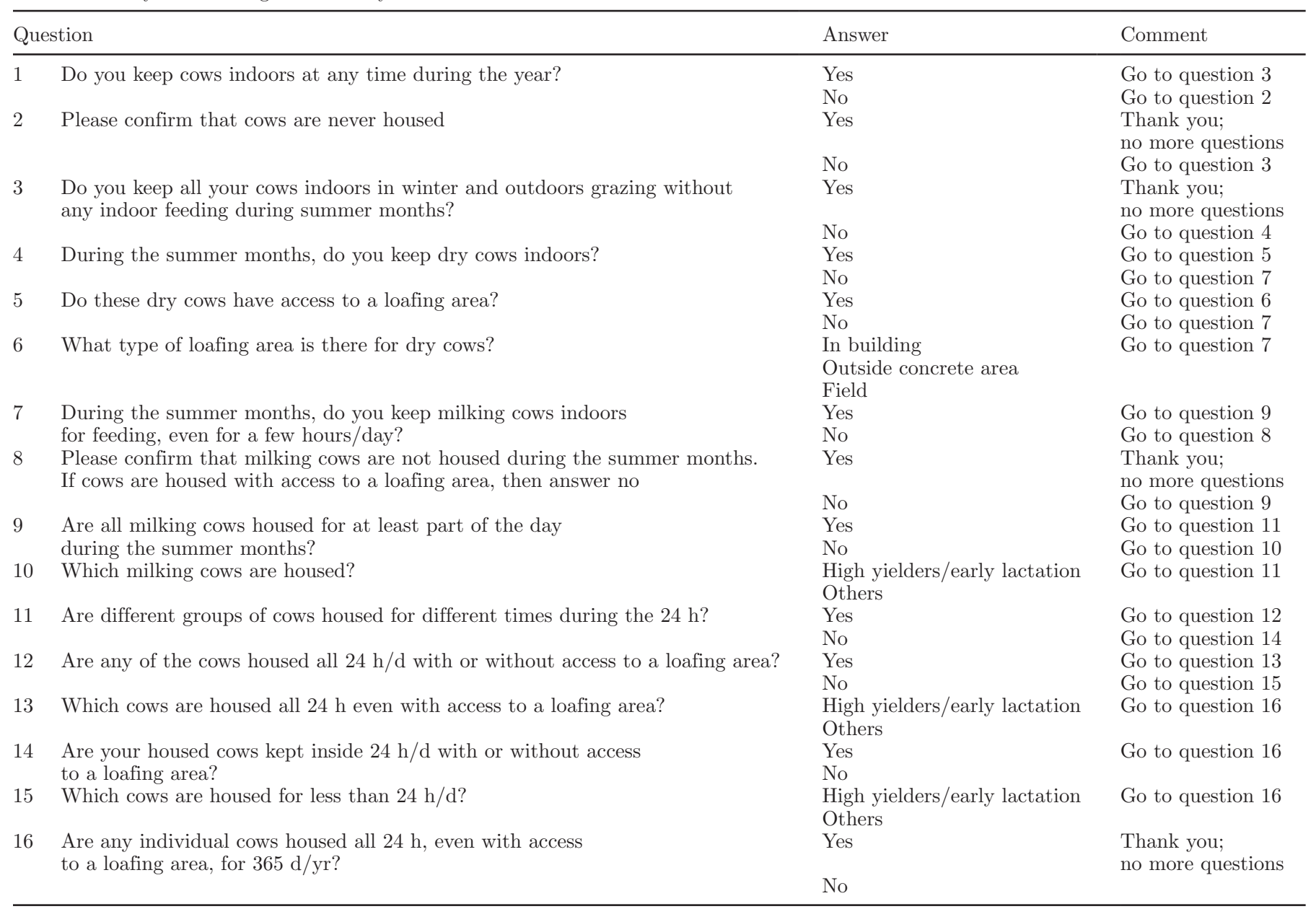


863 Survey

Responses

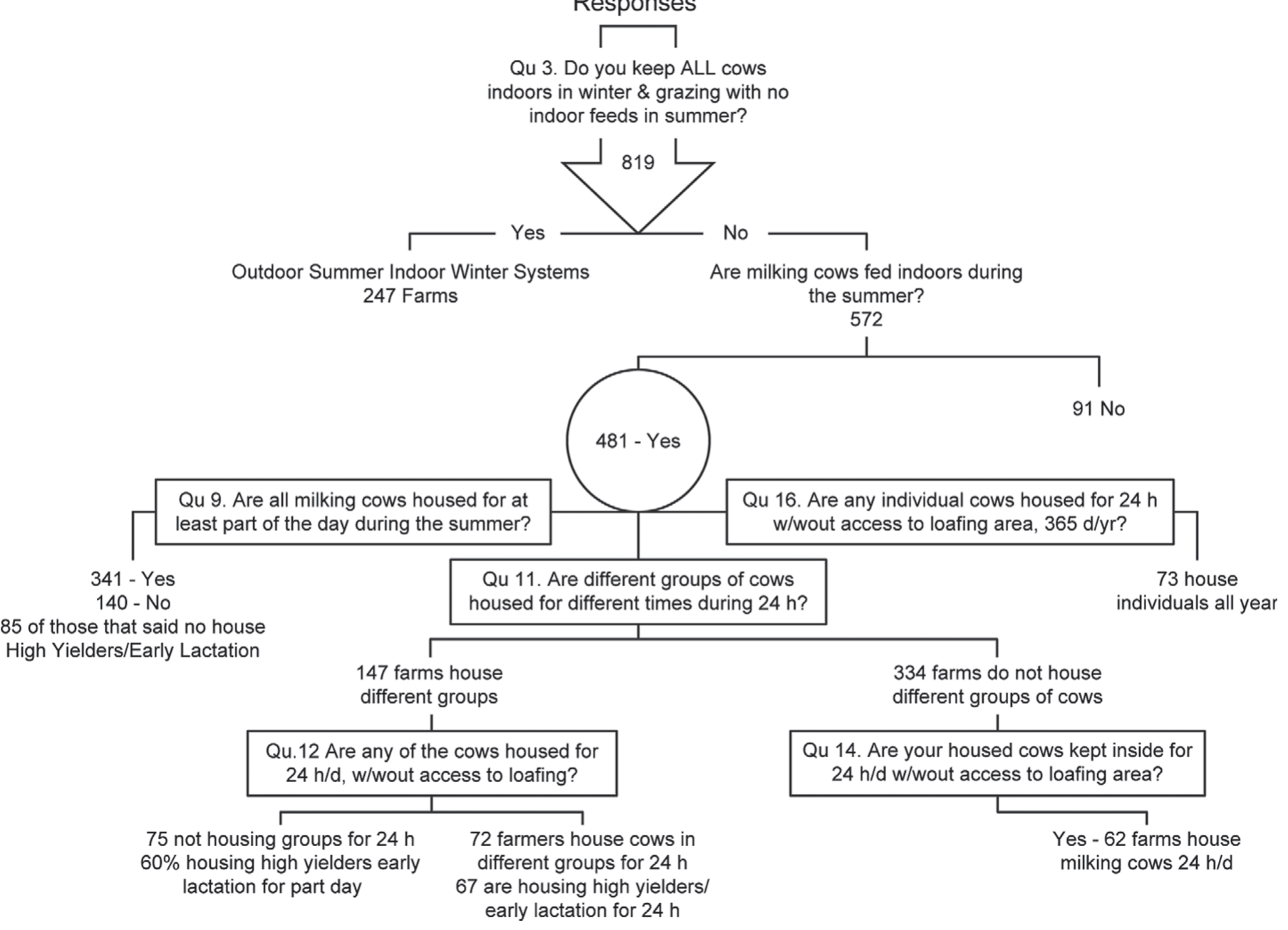

Figure 1. Flowchart of survey responses.

farmers who grazed their milking cows in summer and did not indoor feed $(\mathrm{n}=247)$; $(2)$ indoor fed: farmers who fed all milking cows inside each day during the summer $(\mathrm{n}=301)$; and (3) indoor housed: farmers who housed milking cows for $24 \mathrm{~h} / \mathrm{d}$ during lactation ( $\mathrm{n}=$ $61)$.

The dairy farming system types identified by DairyCo analysis were as follows: cows at grass (mainly grass based); composite (mixed approach to feeding and housing); and high-output cows (housed for more of the year than cows in the other systems; DairyCo, 2012). Respondents who engaged in management systems that did not treat all milking cows in the same manner and fed specific cows or groups were not analyzed. A data set containing the 3 distinct response groups was created and statistical analysis was carried out in SAS software (version 9.2, SAS Institute Inc., Cary, NC) using chi-square, tables, and PROC LOGISTIC. Forty respondents indicated that all their milking cows were indoor fed as well as indoor housed; these cases were removed from the indoor-fed group for the analysis to avoid double counting.

The 3 response variables (herd size, prevalent breed type, and location) were categorized; Table 2 shows the categories applied to each variable collected in the survey. To create a proxy for climate and grass growth potential, the location variables were categorized by the estimated grassland productivity in each area expressed in decitonnes per hectare (where 1 decitonne is equal to 0.1 tonne), using a model described by Smit et al. (2008). Prevalent breed types were classified into 3 groups: (1) Holstein/Friesian (HF) herds: those that farmed with Holsteins, Friesians, or Holstein-Friesians; (2) other pure-breed herds: those that farmed with 
Table 2. Categories applied to response variables herd size, breed type, and farm location

\begin{tabular}{llll}
\hline Item & Breed type & Herd size & County location \\
\hline Classification method & Common types & Survey average \pm 1 SD & Grassland productivity (decitonne/ha) \\
Category & Pure breeds & Below average & $<80$ \\
& Mixed breeds & Average & $80-90$ \\
& Holstein, Friesian, or Holstein-Friesian & Above average & $90-100$ \\
\hline
\end{tabular}

other pure breeds such as Ayrshire or Jersey; and (3) mixed-breed herds: farmers having more than one breed type in their herd.

Herd size categories shown in Table 2 are defined as below average, average, and above average. The survey average herd size of 174 (SD: 117) \pm 1 standard deviation was applied to give an average range because it was comparable with other published figures (DairyCo, 2012).

Chi-squared tests were carried out to investigate possible relationships between management group and the 3 response variables. Test statistics and degrees of freedom were evaluated and significance levels determined in each case. Logistic regression was carried out using SAS software (SAS Institute Inc.) to establish significance of the predictors and any interactions between them.

\section{RESULTS}

Responses were received from $863(6 \%)$ dairy production holdings distributed across 63 counties in Britain, stretching from Cornwall in the south of England to the Orkney Isles in the north of Scotland. Compared with figures for holdings in England, the most common survey response counties corresponded with those counties having the greatest number of dairy farms (Devon, Cumbria, Cheshire, Staffordshire, Somerset, and Lancashire; DairyCo, 2010). Responses from Scottish dairy counties were consistent with figures for numbers of holdings per region (Scottish Government, 2011). Dairy farms are less common or nonexistent in some parts of the country and, as expected, some counties (e.g., Sunderland, Caithness, and Tyneside) yielded no survey responses. Herds with fewer than 10 cows in England were not well represented and these herds contain $1 \%$ of the 1.1 million cows in England (DairyCo, 2014a).

Of the 863 responses, 5 farmers kept their cows outside all year, 26 farmers fed additional forage without housing, and 13 surveys were incomplete. The surveyed herds contained 139,467 cows, which represented $9 \%$ of the 1.5 million adult dairy cows in Britain in 2011 (DairyCo, 2012). Figure 2 shows the distribution of breed type within surveyed farms and shows that Holstein, Holstein-Friesian, Friesian, and Ayrshire breeds were found on $92 \%$ of farms. These breed types also accounted for $94 \%$ of all cows within the survey. Of all respondents the average herd size was 174 cows, whereas the mode was 130 cows and the range was 10 to 1,200 cows.

Figure 3 outlines the survey percentage responses grouped by management style. More than two-thirds of respondents have adopted some form of indoor summer feeding system, and only 31\% (247) farmed with forage solely from grazing during the summer months. Of all respondents, $38 \%$ (301) indicated that they were feeding all their milking cows inside during the summer for part of the day. Those farmers who did not feed all milking animals inside in summer months tended to feed specific groups of cows indoors for part of the day, such as high yielders or those in early lactationthis accounted for $10 \%$ of farmers. Approximately $8 \%$ of respondents have adopted a system in which their milking herd are fed and housed inside all year and an additional $8 \%$ of farmers are continuously housing their high yielding or early lactation cows. Figure 3 shows response numbers to survey questions (other than those relating to dry cows) and highlights that 55\% (481) of all respondents are feeding milking cows inside during the summer.

Analysis was carried out with 3 distinct response groups to determine any relationship between management style and the 3 response variables. The box plot in Figure 4 illustrates that as herd size increases, farmers tend to move from a traditional grazing system toward continuously housing their cows during the summer. The average herd size of the $31 \%$ of farms that operated grazing systems and did not indoor feed in summer was 137, whereas herd size averaged 270 in the $8 \%$ of farms that practiced some form of continuous housing with all their milking cows. Results indicated that farmers with larger herds predominantly have Holstein and Holstein-Friesian breeds, and of those respondents that fed and housed their cows inside during the summer, $98 \%$ farmed with these breed types.

Chi-squared tests showed a significant relationship between herd size and management style adopted by the farmer, and also a significant relationship between management style and breed. Farm location, categorized by regional grassland productivity, showed no 


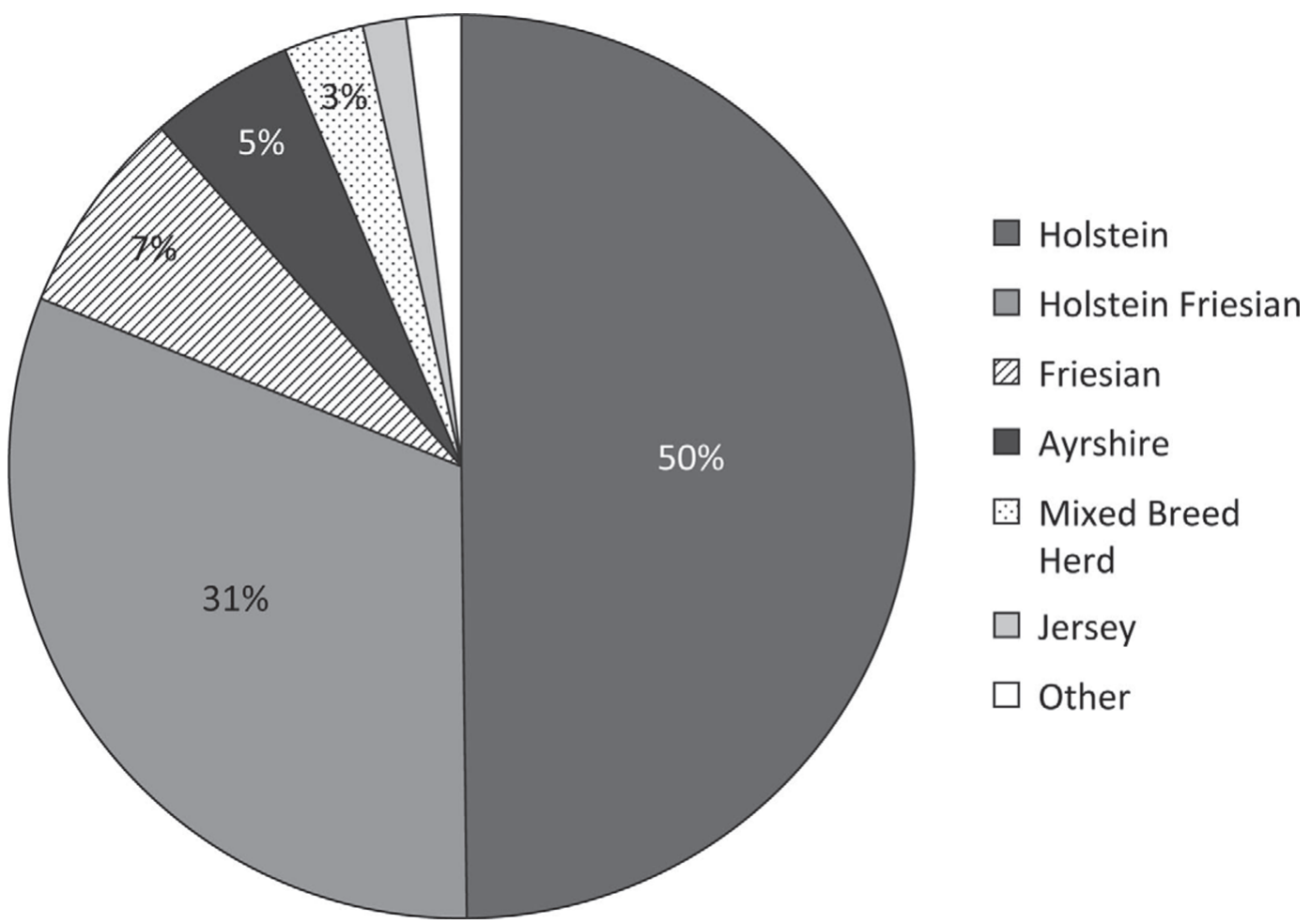

Figure 2. Distribution of breed types across surveyed farms. Other breeds include Montbéliarde, Brown Swiss, Shorthorn, Guernsey, and Swedish Red.

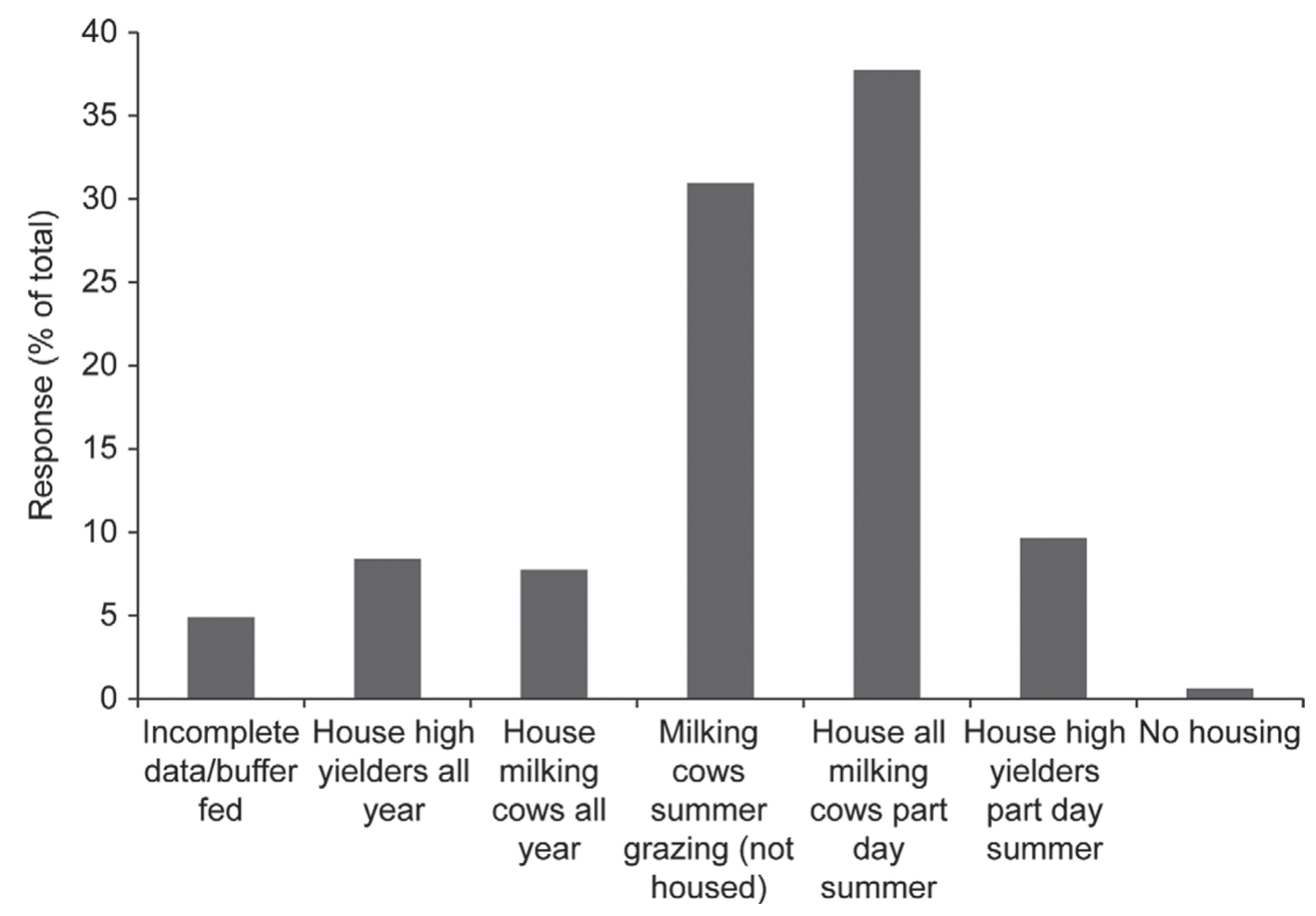

Figure 3. Survey responses by percentage of total and grouped by management style. 


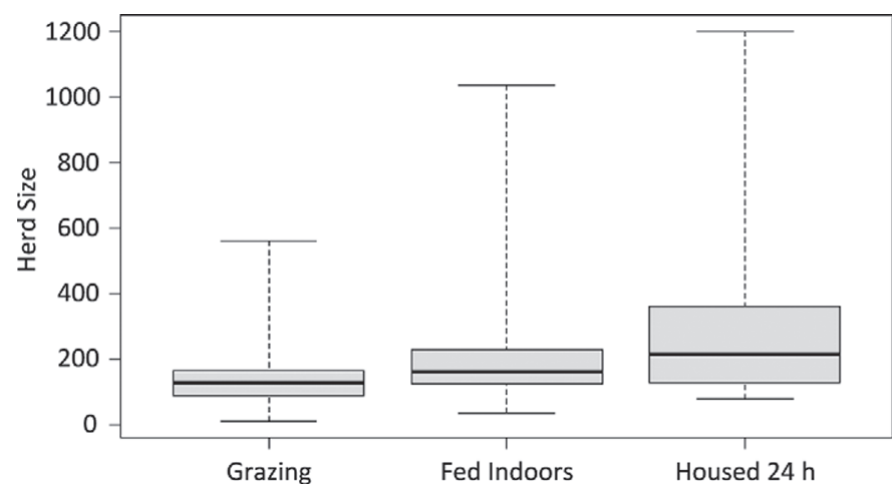

Figure 4. Boxplot showing median and range of herd sizes within each management group.

significant relationship to management group. Table 3 shows the value of the test statistic along with its significance.

Multinomial logistic regression was carried out with the dependent categorical variable management group, having 3 outcomes. The predictor variable herd size was continuous and the breed variable was categorical. Analysis of effects showed that none of the predictor variables or any interactions between them were significant at predicting the management group even though the model was a better fit with the covariates included.

\section{DISCUSSION}

The principal reasons for carrying out this survey were to assess the prevalence of various dairy production methods in Great Britain and to identify the proportion of dairy cows that were continually housed. The main finding of this study was that the traditional British dairy management style of all-summer grazing and winter-only indoor feeding was practiced by less than one-third of respondents. More than half of respondents $(55 \%, 481)$ were feeding cows indoors in summer, which could be due, in part, to nutritional factors, as Holstein cows of high genetic merit are not able to produce a maximal amount of milk per lactation from grazing only (Peyraud et al., 2010). In 2005, it was estimated that $95 \%$ of dairy holdings in the UK farmed with grazing as part of their dairy management system (Van den Pol-van Dasselaar et al., 2008), and assuming that this is not an effect of not including farms in Northern Ireland, our survey suggests it has decreased to $92 \%$ in the last $8 \mathrm{yr}$.

Grazing has been found to be declining in many countries, and farmers have implemented increased housing for environmental, feeding, or management purposes, or because local climate restricts choices (Van den Pol-van Dasselaar et al., 2008; Reijs et al., 2013; Margerison et al., 2014). It could be argued that it is often easier for grassland farmers wishing to enhance production or herd size to import purchased feeds than to increase their available land area. Reasons for a shift away from grazing can include difficulty in controlling feed rations for high-yielding animals, an uncertainty of grass supply in some countries, practical difficulties (such as walking distances and lying times), and the availability of a stable labor force (Van den Pol-van Dasselaar et al., 2011). The performance of a high-yielding cow can demand up to 5 times its maintenance requirement for energy and it may be difficult to achieve this by a grazing and silage-based diet; hence, some additional feeding is required (Huxley and Green, 2010).

Within the European Union, a broad geographical and cultural boundary supports a wide range of intensive and extensive dairy systems, and shifting away from grazing is not solely a British phenomenon (Bourgeois, 2002; Van den Pol-van Dasselaar et al., 2011). In the United States, there has been an increase in housed systems that deliver harvested forage to the cows, and $63.9 \%$ of operations containing $82.2 \%$ of US cows are found in housed systems (USDA-NASS, 2010). In countries such as New Zealand and Ireland, housed systems are uncommon and extensive spring-calving grazing systems are the standard method of milk production for the majority of farmers (Van den Pol-van Dasselaar et al., 2011; DairyNZ, 2013). Maintaining larger herds at pasture can be less problematic with robust infrastructure; however, one drawback of spring-calving production systems is an approximate 305-d lactation period, which requires the whole herd to be back in calf within a set period (Buckley and Dillon, 1998).

The merits of retaining an assortment of dairy systems nationally may not always be obvious, apart from the availability of a year-long milk supply. In some systems, calving patterns could dictate housing requirements, as extended lactations combined with yearround calving can result in some cows being housed for

Table 3. Chi-squared test results

\begin{tabular}{lll}
\hline Hypothesis $\mathrm{H}_{\mathrm{o}}$ & Result & Significance \\
\hline There is an association between management style and herd size & $\chi^{2}(4)=42.98$ & $P<0.0001$ \\
There is an association between management style and breed type & $\chi^{2}(4)=19.51$ & $P<0.001$ \\
There is an association between management style and location & $\chi^{2}(4)=2.31$ & Not significant \\
\hline
\end{tabular}


longer, as persistency in high-yielding cows can result in lactations of up to $450 \mathrm{~d}$ (Knight, 2005). Calving all year spreads labor requirements, and the housing of cows can result in reduced impacts because of the ability to better manage manure, which can result in lower greenhouse gas emissions and increases in nutrient use efficiency. Capper et al. (2009) highlighted the environmental efficiency of modern US dairy production methods by demonstrating that the same quantity of milk can be produced with $90 \%$ less land and $75 \%$ fewer cows than were required in 1944. Shifts within the UK dairy sector can be described by comparing key production indicators, and Table 4 illustrates that increased average yields per cow have compensated for reductions in herd numbers, offsetting declines in total milk production. Increased knowledge and technological advances are represented by decreases in nitrogen application rates and substantial increases in areas planted with forage maize.

Although it has been reported that the public in Britain is opposed to indoor dairy systems, when consumer awareness of dairy production systems was investigated by surveying the public in Central Scotland and Northern England, many respondents had no understanding of dairying and did not realize that "summer outside, winter inside" has been the traditional method of husbandry in most of the UK (Ellis et al., 2009). When asked directly, $95 \%$ of respondents were not in favor of permanently housing dairy cows; however, when consulted on factors associated with positive welfare, appropriate feeding and good stockmanship had the highest frequency of responses, whereas access to the outdoors was lower (Ellis et al., 2009). Accommodating cows indoors in the UK is not a modern occurrence in 19th century towns, cows were routinely housed to supply urban consumers, and, around Edinburgh, dairy cows were kept in sheds and fed hay produced on meadows irrigated by slurry and human waste (Harvey, 2002).
Housing and management style can affect the welfare of dairy cows. Behavioral studies have shown that loafing areas can benefit housed cows as they provide a space to avoid dominant animals and to cool down in high temperatures (Haskell et al., 2013). Allotting cows more trough space when feeding will lower aggression and, when feeding is restricted, more space is necessary compared with an ad libitum feeding regimen (Metz and Mekking, 1984; DeVries et al., 2004). The Farm Animal Welfare Council acknowledges that housed dairy cows in the UK can have an acceptable standard of welfare as long as suitable housing is provided together with skilled animal husbandry and veterinary practice (FAWC, 2010).

Continually housed dairy cows can be susceptible to a range of health issues; for example, Haskell et al. (2006) showed an increase in foot and leg conditions. The EFSA (2009) report provides a detailed review of literature on the effect of dairy systems on animal welfare and cited a range of studies that indicate housed cows are at greater risk of health disorders such as mastitis and retained placenta; however, innovative techniques used in the United States such as rubber surfacing and deep-bedded freestalls may help lower the incidence of some health issues. Dairy cows maintained in grazing systems are at risk of health issues such as lameness and milk fever (Chesterton et al., 1989; Haskell et al., 2006; Roche and Berry, 2006) and are also exposed to prevailing weather conditions. Direct comparisons of health and welfare within systems are noted to be difficult to assess (EFSA, 2009) and not within the scope of this study; however, the apparent increase in continuous housing of cows in Britain is of concern as standards of care and management must be high.

The analysis presented here illustrates that increased herd size can be associated with a transition from lowinput grazing to more intensive imported feed-based systems. Large herds can be more difficult to manage in

Table 4. Key production indicators ${ }^{1}$ in the United Kingdom in 1980 and 2010

\begin{tabular}{lcc}
\hline Variable & 1980 & 2010 \\
\hline Total milk production $^{1}\left(\times 10^{6} \mathrm{~L}\right)$ & 15,409 & 13,322 \\
Dairy herd $\left.^{1} \times 10^{3}\right)$ & $3,260^{2}$ & $1,847^{1}$ \\
Average milk yield per cow $^{1}(\mathrm{~L})$ & $4,727^{2}$ & $7,375^{1}$ \\
Average milk fat content $^{3}(\%)$ & 3.88 & 3.96 \\
Average protein content $^{3}(\%)$ & 3.40 & 3.28 \\
Average herd size $^{1}$ & 58 & 121 \\
${\text { Maize harvest }\left(\times 10^{3} \text { ha) }\right.}_{\text {Nitrogen fertilizer application grass }}^{4}(\mathrm{~kg} / \mathrm{ha})$ & 125 & 63 \\
${ }^{1}$ DairyCo (2014b). & & \\
${ }^{2}$ Defra (2010). & & \\
${ }^{3}$ Defra (2011b). & & \\
${ }^{4}$ Defra (2011a). & &
\end{tabular}


grass-based systems: if land is constrained, more cows increase stocking rates, which can cause pressure on available grazing; if land not limited, distance from the parlor will restrict its use (Van den Pol-van Dasselaar et al., 2008). Alternatively, increased herd size may be associated with purchased feed-based systems because they tend to become viable with larger numbers of cows (DairyCo, 2013b). Herd sizes in the UK have increased from an average of 20 cows in 1960 to around 123 today (Defra, 2012). The UK is 1 of only 11 countries with dairy herd sizes averaging over 100 animals, the others being Saudi Arabia, South Africa, New Zealand, Australia, the Czech Republic, Argentina, United States, Denmark, Israel, and Cyprus (IFCN, 2014). Increasing herd size is not a UK phenomenon and is occurring throughout most European Union member states; however, herd sizes on farms vary significantly between countries. For example, over $75 \%$ of dairy cows in Romania are kept in herds of fewer than 10, whereas 97\% of dairy cows in Cyprus and Denmark are kept in herds of $>100$ (European Commission, 2012) and 25\% of herds in New Zealand contain $>500$ cows (DairyNZ, 2012).

European herds could be considered small compared with those in the United States, where $30 \%$ of commercial farms hold $>2,000$ cows (USDA-NASS, 2010), and Saudi Arabia, where there are maximums of 30,000 cows per holding (Alvis et al., 2012). Since the turn of the century, the United States has experienced similar dairy industry reforms, as the number of holdings has declined by $33 \%$ even though milk output and cow numbers have increased. Farms with large herds ( $>500$ cows) and very large herds $(>2,000$ cows) have increased by 20 and $128 \%$, respectively, between 2001 and 2010, whereas $35 \%$ of farms with fewer than 500 cows are no longer in business (USDA-NASS, 2010).

This study found no association between management type and farm location, which might indicate that although extensive grazing systems would be expected to be located in the best grass-growing areas, more intensive housed systems could theoretically be based anywhere in the country. Between 2002 and 2012, UK counties that lost more than half of their dairy farms were mainly located in the eastern and central parts of the country (DairyCo, 2013b). This could suggest that over the last decade, systems located in the wetter parts of the UK have been more robust to increases in purchased feed, fertilizer, and transport costs. Farmers reliant on imports of wheat and soy may also face higher costs if their farms are located some distance from a port. A significant association between management group and breed type was expected because pure (nonHF) and mixed-breed herds had predominantly grazing systems and were largely absent from the indoor feed- ing systems. Industry trends suggest that farmers are developing larger herds with higher yields per cow, and these larger herds tend to contain HF breeds.

This snapshot of the dairy industry shows that farmers in Britain seem to be shifting from traditional techniques that have been commonplace for at least the last $50 \mathrm{yr}$ to systems that require more-targeted nutrition strategies to satisfy a heavier dairy cow of higher genetic merit, yielding twice as much milk per lactation as it did in the past. The survey results seem representative of the prevalence of British dairy management systems, as the percentage of continuously housed systems was in agreement with the results of a farm practices survey (Defra, 2013) and also a national mastitis survey (Biggs, 2012). Sampling methodology might have been improved by proportional allocation or stratification. Responses were gathered from across Britain and the frequency of responses from each county was consistent with farm dairy location data (DairyCo, 2010). As is the case with most surveys, a higher number of overall responses would have been welcomed.

\section{CONCLUSIONS}

Information gathered from British dairy farmers provided a snapshot of the industry's structure and showed a mix of feeding and housing practices. The traditional system, where all cows graze all day in summer, is no longer the predominant management system in operation. Other systems such as year-round indoor feeding and continuous housing are becoming more common. On average, herd sizes are larger in more-intensive systems and the preferred breed is the higher-yielding Holstein-Friesian cow. If these trends continue, more farmers may choose to opt for intensive nongrazing dairy production systems. Stakeholders and the public should be informed of current industry structures and the benefits of more intensive dairy systems to understand and accept the merits of varied management regimens. Comparisons show that herd-size trends and UK dairy management methods are not dissimilar to those found in other parts of the world.

\section{ACKNOWLEDGMENTS}

The farm survey was funded by Defra (Department for Environment, Food and Rural Affairs, London, UK) and the Scottish Government's RESAS Division, which provides core funding for Scotland's Rural College (SRUC) Dairy Research Centre (Dumfries). The SRUC conducted this research with the assistance of the Cattle Information Service (CIS, Rickmansworth, UK). The authors are grateful to farmers who completed the survey, and to Nicola Boyes (SRUC, Edinburgh, UK). 


\section{REFERENCES}

Alvis, D., A. Jackson, and J. Allen. 2012. Can big be beautiful? The relationship between size of unit and sustainability in housed livestock systems. Royal Agricultural Society of England. Accessed Sep. 22, 2014. http://www.appg-agscience.org.uk/linkedfiles/ WCFLivestockReportFullOct2012.pdf.

Biggs, A. 2012. The national mastitis survey 2012. Pages 39-57 in Proc. British Mastitis Conf. Worcester, The Dairy Group, The University of Nottingham and DairyCo. Accessed Sep. 22, 2014. http:// www.britishmastitisconference.org.uk/BMC2012\%20proceedings. pdf.

Bourgeois, L. 2002. Common agricultural policy and grasslands: The case study of France. Grassl. Sci. Eur. 7:5-15.

Buckley, F., and P. G. Dillon. 1998. The effect of genotype and feeding system on the performance of Holstein Friesian cows at pasture. Pages 1-15 in Proc. Irish Grassland Association Dairy Conf., Limerick, Ireland. Irish Grassland Assoc., Kells, Co. Meath, Ireland.

Capper, J. L., R. A. Cady, and D. E. Bauman. 2009. The environmental impact of dairy production: 1944 compared with 2007. J. Anim. Sci. 87:2160-2167.

Chesterton, R. N., D. U. Pfeiffer, R. S. Morris, and C. M. Tanner. 1989. Environmental and behavioural factors affecting the prevalence of foot lameness in New Zealand dairy herds-A case-control study. N. Z. Vet. J. 37:135-142.

DairyCo. 2009. Desktop review of greenhouse gas (GHG) emissions. DairyCo, part of Agriculture and Horticulture Development Board. Report. Warwickshire Accessed Sep. 8, 2013. http://www.dairyco. org.uk/resources-library/technical-information/climate-change/ desktop-review-of-greenhouse-gases/.

DairyCo. 2010. Cows numbers by county. Accessed Sep. 8, 2013. http://www.dairyco.org.uk/market-information/farmingdata/cow-numbers/uk-cow-numbers/.

DairyCo. 2012. Profiting from efficient milk production: Key findings of the Milkbench+ dairy benchmarking programme regarding the efficiency of dairy production in Britain. DairyCo/Agriculture and Horticulture Development Board, Warwickshire, UK.

DairyCo. 2013a. Dairy Market Update December 2013. Accessed Dec. 10, 2013. http://www.dairyco.org.uk/resources-library/marketinformation/dairy-market-update/.

DairyCo. 2013b. The structure of the GB dairy farming industryWhat drives change? Accessed Dec. 10, 2013. http://www.dairyco. org.uk/non_umbraco/download.aspx?media $=14129$.

DairyCo. 2013c. Monthly milk production. Accessed Dec. 10, 2013. http://www.dairyco.org.uk/resources-library/market-information /supply-production/monthly-milk-production.

DairyCo. 2014a. Cow numbers distribution by herd size. Accessed May 31, 2014. http://www.dairyco.org.uk/resources-library/marketinformation/farming-data/distribution-by-size/.

DairyCo. 2014b. On farm data. Accessed May 31, 2014. http://www. dairyco.org.uk/market-information/farming-data/.

DairyCo. 2014c. Producer numbers. Accessed Dec. 10, 2013. http://www. dairyco.org.uk/resources-library/market-information/farmingdata/producer-numbers/.

DairyNZ. 2012. New Zealand Dairy statistics, 2011-2012. Accessed Sep. 22, 2014. http://www.dairynz.co.nz/media/434165/new_ zealand_dairy_statistics_2011-12.pdf .

DairyNZ. 2013. New Zealand Dairy statistics, 2012-2013. Accessed Sep. 22, 2014. http://www.dairynz.co.nz/media/434163/new_ zealand_dairy_statistics_2012-13.pdf .

DeVries, T. J., M. A. G. von Keyserlingk, and D. M. Weary. 2004. Effect of feeding space on the inter-cow distance, aggression and feeding behaviour of free-stall housed lactating dairy cows. J. Dairy Sci. 87:1432-1438.

Defra (Department for Environment, Food and Rural Affairs). 2010. Agriculture in the UK. Table 3.2. Accessed Sep. 22, 2014. http:// archive.defra.gov.uk/evidence/statistics/foodfarm/general/auk/ latest/excel/index.htm.

Defra (Department for Environment, Food and Rural Affairs). 2011a. Composition of milk in the UK. Accessed Mar. 14, 2011. http:// webarchive.nationalarchives.gov.uk/20130123162956/http://www. defra.gov.uk/statistics/files/defra-stats-foodfarm-farmgate-milk price-dataset-130108.xls.

Defra (Department for Environment, Food and Rural Affairs). 2011b. The British survey of fertiliser practice: fertilizer use on farm crops for the year 2011. https://www.gov.uk/government/uploads/ system/uploads/attachment_data/file/181432/defra-statsfoodfarm-environ-fertiliserpractice-2011-120425.pdf.

Defra (Department for Environment, Food and Rural Affairs). 2012 Statistics: Milk production http://archive.defra.gov.uk/evidence/ statistics/foodfarm/enviro/observatory/indicators/b/b11_fact. htm.

Defra (Department for Environment, Food and Rural Affairs). 2013. Farm practices survey Autumn 2012. Accessed Jan. 24, 2014. https:// www.gov.uk/government/uploads/system/uploads/attachment _data/file/181719/defra-stats-foodfarm-environ-fps-statsreleaseautumn2012edition-130328.pdf.

Ellis, K., K. Billington, B. McNeil, and D. E. F. McKeegan. 2009. Public opinion on UK milk marketing and dairy cow welfare. Anim. Welf. 18:267-282.

European Commission (EC). 2012. Eurostat Agricultural Statistics 3.5.3.6: Dairy cow numbers and numbers of holders. Accessed Jan. 12, 2014. http://www.ec.europa.eu/agriculture/statistics/ agricultural/2012/pdf/full-report_en.pdf.

EFSA (European Food Safety Association). 2009. Scientific report of EFSA prepared by the Animal Health and Animal Welfare Unit on the effects of farming systems on dairy cow welfare and disease. EFSA J. 1143:1-7.

FAOSTAT. 2013. Commodities production countries by commodity; milk whole fresh cow. Accessed Dec. 10, 2013. http://faostat.fao. org/site/339/default.aspx.

FAWC (Farm Animal Welfare Council). 2010. Welfare of dairy cows letter to ministers. Accessed Dec. 10, 2013. http://www.fawc.org. $\mathrm{uk} / \mathrm{pdf} /$ cows-welfare-letter.pdf.

Harvey, G. 2002. The Forgiveness of Nature. Vintage, London, UK.

Haskell, M. J., K. Maslowska, D. Bell, and D. J. Roberts. 2013. The effect of a view to the surroundings and microclimate variables on use of a loafing area in housed dairy cattle. Appl. Anim. Behav. Sci. $147: 28-33$.

Haskell, M. J., L. J. Rennie, V. A. Bowell, M. J. Bell, and A. B. Lawrence. 2006. Housing systems, milk production and zero-grazing effects on lameness and leg injury in dairy cows. J. Dairy Sci. 89:4259-4266.

Huxley, J., and M. Green. 2010. More for less: Dairy production in the 21st century. Vet. Rec. 167:712-713.

International Farm Comparison Network (IFCN). 2014. World dairy map 2014. Results of the IFCN dairy report 2013. Accessed Sep. 22, 2014. http://www.ifcndairy.org/media/downloads/ WDM-2014-low.pdf.

Knight, C. 2005. Extended lactation: Turning theory into reality. Adv. Dairy Technol. 17:113-123.

Margerison, J. K., J. Lau, M. J. Hedley, D. J. Horne, J. A. Hanly, N. Powell, and A. Shilton. 2014. Lying and feeding behavior of dairy cows at pasture and housed in free stalls fitted with sand and water filled mats. Occasional Report no. 27. Fertilizer and Lime Research Centre, Massey University, Palmerston North, New Zealand. Accessed May 26, 2014. http://www.massey.ac.nz/ flrc/ workshops/14/Manuscripts/Paper_Margerison_2014.pdf.

Metz, J. H. M., and P. Mekking. 1984. Crowding phenomena in dairy cows as related to available idling space in a cubicle housing system. Appl. Anim. Behav. Sci. 12:63-78.

Peyraud, J. L., P. Dupraz, E. Samson, A. Le Gall, and L. Delaby. 2010. Producing milk at grazing to reconcile economic and environmental performances. Grassl. Sci. Eur. 15:865-876.

Reijs, J. W., C. H. G. Daatselaar, J. F. M. Helming, J. Jager, and A. C. G. Beldman. 2013. Grazing dairy cows in North-West Europe; Economic farm performance and future developments with emphasis on the Dutch situation. LEI Report 2013-001. LEI (Landbouw Economisch Instituut), Wageningen University and Research Centre, The Hague, the Netherlands. 
Roche, J. R., and D. P. Berry. 2006. Periparturient climatic, animal, and management factors influencing the incidence of milk fever in grazing systems. J. Dairy Sci. 89:2775-2783.

Scottish Government. 2011. Economic report on Scottish agriculture: Table C1-Number of holdings per region. Accessed Aug. 21, 2014. http://www.scotland.gov.uk/Publications/2011/06/15143401/61.

Smit, H. J., M. J. Metzger, and F. Ewert. 2008. Spatial distribution of grassland productivity and land use in Europe. Agric. Syst. 98:208-219.

USDA-NASS (National Agricultural Statistics Service). 2010. Overview of the United States dairy industry. Accessed Sep. 20, 2013. http:/ usda.mannlib.cornell.edu/MannUsda/viewDocumentInfo.do? documentID $=1831$
Van den Pol-van Dasselaar, A., A. de Vliegher, D. Hennessey, J. L. Peyraud, and J. B. Pinxterhuis. 2011. Research methodology of grazing. Proc. EGF Working Group Grazing. Report 405. Livestock Research, Wageningen University, Wageningen, the Netherlands.

Van den Pol-van Dasselaar, A., T. V. Vellinga, A. Johansen, and E. Kennedy. 2008. To graze or not to graze, that's the question. Biodiversity and animal feed: Future challenges for grassland production. Grassl. Sci. Eur. 13:706-716. 